Diabetologia 8, 196-201 (1972)

(C) by Springer-Verlag 1972

\title{
Correlations between Plasma Insulin and Body Weight in Obesity, Anorexia Nervosa and Diabetes mellitus*
}

\author{
F. Stephan, Ph. Reville, R. Thierry and J.L. Schlienger \\ Clinique Endocrinologique, C.H.V. Strasbourg, France
}

Received: December 1, 1971, accepted: January 31, 1972

\begin{abstract}
Summary. Determinations of plasma insulin levels (IRI) were performed in 79 patients before and after a quick intravenous glucose load $(0.33 \mathrm{~g} / \mathrm{kg}$ body weight). The patients wore divided in normals $(\mathrm{N})$, underweight patients $(M)$, obese $(\mathrm{O})$, latent diabetics (D1) and overt diabetics (D2), obese latent diabetics (OD1) and obese diabetics (OD2). The body weight varied from 59 to 290 per cent of ideal body weight and the age from 14 to 75 years. We were unable to find any significant correlation between basal IRI values and body weight. We found significant correlations between IRI values obtained after glucose administration and body weight. The insulinogenic index rises with increasing body weight in all subjects, in non diabetics (N-M-O) as well as in diabetics (D1D2-OD1-OD2). In undernutrition due to anorexia nervosa, the basal plasma IRI and the plasma IRI increase after the glucose load are normal in the studied patients. Overt diabetic patients (D2 and OD2) were significantly older than non diabetic patients having the same body weight (N-O). The insulinogenic index fell with increasing age in obese and in diabetic patients. The correlations between plasma IRI and blood sugar are discussed.
\end{abstract}

Correlations entre l'insulinémie et le poids corporel chez des obèses, des dénutris et des diabétiques

Résumé. Chez 79 patients nous avons pratiqué des épreuves rapides d'hyperglycémie provoquée par voie $\mathrm{I}$. $\mathrm{V} .(0.33 \mathrm{~g}$ de glucose $/ \mathrm{kg}$ poids corporel) et dosé parallèlement l'insulinémie plasmatique (IRI). Les sujets étudiés se répartissent en normaux $(\mathrm{N})$, dénutris par anorexie mentale $(M)$, obèses $(O)$, diabétiques latents de poids normal (D1), diabétiques patents de poids normal (D2), obèses diabétiques latents (OD1) et obèses diabétiques patents (OD2). Chez l'ensemble des sujets, les poids varient de 59 à 290 pour cent du poids idéal et les âges s'étendent de 14 à 75 ans. Nous ne trouvons aucune relation significative entre l'TRI basale et le poids corporel. Par contre, la riposte insulinique au glucose, en particulier l'index insulinogénique, s'élève en fonction du poids corporel chez tous les sujets, chez les non diabétiques (N-MO) comme chez les diabétiques (D1-D2-OD1-OD2). Les dénutris par anorexie mentale ont une insulinémie basale normale; leur riposte insulinique au glucose est normale du moins chez les sujets étudiés dans ce travail. Il s'est avéré que les diabétiques (D2 et OD2) sont significativement plus âgés que les témoins (N-O) de même poids corporel. L'index insulinogénique s'abaisse en fonction de l'âge chez les obèses et les diabétiques. Les relations entre l'insulinémie et la glycémie sont discutées.

Beziehungen zwischen Plasmainsulin und Körpergewicht bei Fettsucht, Anorexia nervosa und Diabetes mellitus

Zusammenfassung. Bei 79 Patienten wurde der Plas. ma-Insulinspiegel (IRI) vor und nach rascher intravenö. ser Gabe von Glucose ( $0.33 \mathrm{~g} / \mathrm{kg}$ Körpergewicht) bestimmt. Die Patienten wurden in verschiedene Gruppen eingeteilt: Stoffwechselgesunde (N), Unterernährte (M), latente Diabetiker (D1), Diabetiker (D2), Fettsüchtige (O), fettsüchtige latente Diabetiker (OD1) und fettsüch. tige Diabetiker (OD2). Das Körpergewicht schwankte zwischen $59 \%$ und $290 \%$ des idealen Körpergewichts. Das Alter lag zwischen 14 und 75 Jahren. - Wir fanden keine Korrelation zwischen dem Nüchtern-IRI-Wert und dem Körpergewicht. Jedoch bestanden signifikante Korrelationen zwischen den IRI-Werten nach Glucose-Gabe und dem Körpergewicht. Insbesondere stieg das Verhältnis IRI zu Blutzucker mit wachsendem Körpergewicht bei allen Patienten, bei den Diabetiker (D1-D2OD1-OD2) und bei den Nicht-Diabetiker (N-M-O). Die untersuchten unterernährten Patienten (Anorexia nervosa) haben einen normalen Nüchternwert des IRI im Plasma sowie eine normale Erhöhung der IRI-Plasmawerte nach Glucosegabe. Die Diabetiker D2 und OD2 sind bei gleichem Körpergewicht signifikant älter als die Nicht-Diabetiker $N$ und O. Das Verhältnis Plasma-IRI zu Blutzucker sinkt signifikant mit zunehmendem Alter bei fettsüchtigen und diabetischen Patienten. Die Korrelation zwischen Plasma-IRI und Blutzucker wird erörtert.

Key words: Intravenous glucose load, anorexia nervosa, obesity, maturity onset diabetes, insulinogenic index and body weight, insulinogenic index and age, basal plasma insulin and body weight.
Since the description of the immuno-assays of endogenous plasma insulin by Yalow and Berson [37] and by Grodsky and Forsham [16] it is well established that obesity increases the plasma immunoreactive insulin level (IRI) determined under basal conditions or

* This study has been performed with the support of the "Fondation pour la Recherche Médicale Française" at the "Clinique endocrinologique" (Prof. F. Stephan) and the "Laboratoire d'Immunologie générale" (Prof. R. Minck), C.H.U. de Strasbourg F 67. after a glucose load $[1,2,4,5,6,7,10,13,14,18,19$, $20,21,22,24,27,28,29,30,31,32,35,38]$. Bagdade $e t$ al. [3] and Porte and Bagdade [28] have shown that the increase in IRI after an oral glucose load is a direct function of the basal IRI value. They also found a close correlation between basal plasma IRI and body weight $[2,3,4,28]$. We studied this problem using an intravenous glucose load and adding to groups of normal and obese people a group of undernourished patients. So the weights vary from 59 to 290 per cent 
ideal body weight. Some patients are latent or overt diabetics: others have no detectable disturbance of carbohydrate metabolism. Disregarding body weight, it may be interesting to know if the relation between IRI and body weight is the same in diabetics and in non diabetic patients. Finally, in the whole group the age varied from 14 to 75 years. So we had also to consider this factor because it is known that glucose tolerance is reduced in elderly people, the mechanism of this disturbance being still under discussion.

\section{Methods}

We perform intravenous glucose loads according to Conard etal. [11]. All the subjects were admitted to the wards at least 2 days before the test. They ate the standard diet of the hospital which provides roughly 2500 calories and, at least, $200 \mathrm{~g}$ carbohydrate per day. Only the malnourished patients, treated for anorexia nervosa, ate less. After an overnight fast the patient received, at 8 A.M. an intravenous load of $0.33 \mathrm{~g}$ of glucose per $\mathrm{kg}$ body weight.

A venous blood sample was drawn at time $0,10,20$, $60 \mathrm{~min}$ for IRI determinations and every ten minutes for blood sugar determinations during $1 \mathrm{~h}$. In many patients, but not in all, an additional sample was obtained 4 min after the load.
The statistical significance of the results was checked by analysis of variance and covariance sometimes completed . by a " $t$ " test. Adjustments, according to Snedecor, are made when the discrepancies between the number of subjects in different groups is too great [33]. As many correlations had to be considered, we do not reproduce the individual, original data on figures but record, on tables, the values of the correlation coefficient " $r$ " and the limit of " $p$ ". If the correlation is significant, we add the value of the regression coefficient " $b$ ".

\section{Patients}

We report the results observed in 79 patients $(41 \mathrm{~F}$, $38 \mathrm{M})$. All the patients studied exhibit an increase in plasma IRI after the glucose load. They are classified according to body weight, glucose disappearance rate " $\mathrm{K}$ " and fasting blood glucose.

We consider an individual as normal when he is free of any major disease. In addition he must have a " $\mathrm{K}$ " value equal or superior to 1.10 , a fasting blood sugar below $105 \mathrm{mg} \%$ and a body weight between 80 and 125 per cent of ideal body weight. The 13 normal subjects $(\mathrm{N})$ are admitted to the hospital for minor neurotic disturbances. The underweight patients (M) are all treated for anorexia nervosa. For the present study we selected only those undernourished patients

Table 1. Mean and range of the values observed in the different groups of patients

\begin{tabular}{|c|c|c|c|c|c|c|c|}
\hline Patients & $n$ & $\begin{array}{l}\text { Sex } \\
\bar{F}\end{array}$ & $\bar{M}$ & Age & $\begin{array}{l}\text { Body weight } \\
\text { (p. cent of } \\
\text { ideal weight) }\end{array}$ & $\mathrm{K}$ & $\begin{array}{l}\text { Fasting } \\
\text { Blood sugar } \\
(\mathrm{g} / \mathrm{L})\end{array}$ \\
\hline Controls $(\mathrm{N})$ & 13 & 4 & 9 & $\stackrel{30}{(18-62)}$ & 96 & 1.45 & 0.86 \\
\hline Anorexia nervosa $(\mathbf{M})^{\mathrm{a}}$ & 8 & 7 & 1 & $\begin{array}{l}(18-62) \\
26 \\
(17-63)\end{array}$ & $\begin{array}{l}(84-121) \\
70 \\
(59-77)\end{array}$ & $\begin{array}{l}(1.16-1.92) \\
1.42\end{array}$ & $\begin{array}{l}(0.67-1.02) \\
0.85\end{array}$ \\
\hline Latent diabetics (D1) & 7 & 2 & 5 & $\begin{array}{c}46-05) \\
(26-69)\end{array}$ & $\begin{array}{l}97 \\
(81-122)\end{array}$ & $\begin{array}{c}(1.10-1.80) \\
0.79 \\
(0.48-1.07)\end{array}$ & $\begin{array}{l}0.93 \\
(0.87-1.03)\end{array}$ \\
\hline Diabetics (D2) & 10 & 3 & 7 & $\begin{array}{l}57 \\
(29-75)\end{array}$ & $\begin{array}{l}114 \\
(94-123)\end{array}$ & $\begin{array}{l}0.65 \\
(0.37-0.95)\end{array}$ & $\begin{array}{l}1.71 \\
(1.10-294)\end{array}$ \\
\hline Obese $(\mathrm{O})$ & 14 & 8 & 6 & $\begin{array}{l}34 \\
(15-58)\end{array}$ & $\begin{array}{l}170 \\
(126-290)\end{array}$ & $\begin{array}{l}1.45 \\
(1.17-2.04)\end{array}$ & $\begin{array}{l}0.86 \\
(0.62-1.00)\end{array}$ \\
\hline Obese latent diabetics (OD1) & 13 & 7 & 6 & $\begin{array}{l}33 \\
(14-63)\end{array}$ & $\begin{array}{c}168 \\
(126-209)\end{array}$ & $\begin{array}{l}0.94 \\
(0.45-1.05)\end{array}$ & $\begin{array}{c}0.88 \\
(0.70-1.00)\end{array}$ \\
\hline Obese diabeties (OD2) & 14 & 10 & 4 & $\begin{array}{l}43 \\
(25-61)\end{array}$ & $\begin{array}{l}168 \\
(136-204)\end{array}$ & $\begin{array}{l}0.77 \\
(0.39-1.07)\end{array}$ & $\begin{array}{l}1.43 \\
(1.05-2.45)\end{array}$ \\
\hline
\end{tabular}

a For this study we selected only those undernourished patients who had a normal " $\mathrm{K}$ " and fasting blood sugar.

IRI was measured with the double antibody method of Hales and Randle [17]. Blood glucose determinations were made with the "Autoanalyser Technicon".

The glucose disappearance rate " $\mathrm{K}$ " was calculated according to Conard et al. [11]. We also determined the IRI and the glucose areas, over the basal levels, for $60 \mathrm{~min}$ as well as the ratio

$$
\frac{\text { IRI area }}{\text { glucose area }} \text { (Insulinogenic index). }
$$

Body weight is expressed as percentage of ideal body weight estimated from the height, according to Lorentz. who had a normal " $K$ ", a normal fasting blood sugar and no starvation ketosis. Obese $(O)$ show no evidence of a disturbed carbohydrate metabolism. Latent diabetics (D1) and obese latent diabetics (OD1) have a " $\mathrm{K}$ " value below 1, 10 and a fasting blood sugar below $105 \mathrm{mg} \%$. Overt diabetics (D2) and obese overt diabetics (OD2) have a low " $K$ " value and a high fasting blood sugar.

Before admission to the wards, these subjects were not treated for diabetes and none had received insulin.

The main characteristics of these patients are recorded on Table 1. 


\section{Results}

1. Plasma IRI in patients of various body weights.

We record on Table 2 the mean values of plasma IRI and the significance of the differences observed between the control group and the 6 groups of patients.

In basal conditions the non obese and the obese patients (whether they are or are not diabetic) show a higher plasma IRI level than the controls. The undernourished patients $\mathrm{M}$ have a normal fasting IRI level.
D1 and D2 diabetics is also higher than in the normal controls. But their IRI areas and their insulinogenic indices do not differ significantly. There is no difference between the mean IRI values seen in obese $(0)$ patients and the mean value seen in obese latent diabetics (OD1). These OD1 patients have significantly higher reactive IRI levels than the overt obese diabetics (OD2). It is noteworthy that the latent diabetics (D1) have the same basal and reactive IRI levels as the overt diabetics (D2).

Table 2. Mean values of plasma IRI before and after an I.V. glucose load, IRI area and Insulinogenic Index

\begin{tabular}{|c|c|c|c|c|c|c|c|c|c|c|c|c|c|}
\hline \multirow[t]{3}{*}{ Patients } & \multicolumn{9}{|c|}{ Plasma IRI $(\mu \mathrm{U} / \mathrm{ml})$} & \multirow{2}{*}{\multicolumn{2}{|c|}{$\begin{array}{l}\text { IRI area } \\
(\mu \mathrm{U} / 60 \mathrm{~min})\end{array}$}} & \multirow{2}{*}{\multicolumn{2}{|c|}{$\begin{array}{l}\text { Insulino- } \\
\text { genic Index }\end{array}$}} \\
\hline & \multicolumn{2}{|c|}{ Basal } & \multicolumn{2}{|c|}{$4 \mathrm{~min}$} & $10 \mathrm{~min}$ & \multicolumn{2}{|c|}{20 min } & \multicolumn{2}{|c|}{$60 \mathrm{~min}$} & & & & \\
\hline & $\overline{\bar{x}}$ & $p$ & $\overline{\bar{x}}$ & $\overline{\bar{x}}$ & $p$ & $\overline{\bar{x}}$ & $p$ & $\overline{\bar{x}}$ & $p$ & $\overline{\bar{x}}$ & $p$ & $\overline{\bar{x}}$ & $p$ \\
\hline 1. Controls $(\mathrm{N})$ & 18 & & 101 & & & 28 & & 25 & & 616 & & 192 & \\
\hline xia nervosa $(\mathrm{M})$ & 26 & N.S. ${ }^{2}$ & 73 & N.S. 46 & N.S. & 40 & N.S. & 29 & N.S. & 647 & N.S. & 209 & N.S. \\
\hline dabetics (D1) & 40 & $<0.01$ & & 78 & N.S. & 53 & $<0.01$ & 56 & $<0.02$ & 1001 & N.S. & 238 & \\
\hline Diabetics (D2) & 40 & $<0.01$ & 56 & N.S. 67 & N.S. & 64 & $<0.001$ & 57 & $<0.001$ & 1121 & N.S. & 232 & N.S. \\
\hline Obese $(\mathrm{O})$ & 41 & $<0.005$ & 149 & N.S. 169 & $<0.005$ & 129 & $<0.001$ & 85 & $<0.001$ & 3607 & $<0.001$ & 559 & $<0.01$ \\
\hline Obese latent diabetics & 15 & & 170 & 100 & & 147 & 1 & 130 & $<0$ & 4560 & & 645 & 0.01 \\
\hline Obese diabetics (OD2) & 30 & $<0.05$ & 90 & N.S. 54 & $<0.05$ & 74 & $<0.05$ & 68 & $<0.05$ & 1533 & $<0.01$ & 266 & N.S. \\
\hline $\mathrm{Ov}$ & & N.S. & & N.S. & & & N.S & & N. & & N.S & & N.S. \\
\hline VCIDUS CDE & & N.S. & & N.S. & $<0.01$ & & $<0.01$ & & N.S. & & $<0.05$ & & $<0.05$ \\
\hline OD1 versus OD2 & & N.S. & & $<0.02$ & $<0.02$ & & $<0.01$ & & $<0.01$ & & $<0.01$ & & $<0.01$ \\
\hline D1 versus D2 & & N.S. & & & N.S. & & N.S. & & N.S. & & N.S. & & \\
\hline
\end{tabular}

a In the 1st part of Table 2 we record the significance of the difference between the mean observed in controls and the means observed in the patients. In the 2 nd part we compare the mean values of different groups of patients. $\mathrm{N}$.S. $=$ Statisticaly not significant $(p>0.05)$.

Table 3. Correlations between plasma IRI and body weight before and after an I.V. glucose load

\begin{tabular}{|c|c|c|c|c|c|c|c|c|c|c|}
\hline \multirow[b]{2}{*}{$y$} & \multirow[b]{2}{*}{$x$} & \multicolumn{3}{|c|}{ All subjects $(n=79)$} & \multicolumn{3}{|c|}{ Non diabetics $(n=35)$} & \multicolumn{3}{|c|}{ Diabetics $(n=44)$} \\
\hline & & $r$ & $p$ & $b$ & $\bar{r}$ & $p$ & $\bar{b}$ & $\bar{r}$ & $p$ & $b$ \\
\hline $\begin{array}{l}\text { basal IRI } \\
\text { log. basal IRI } \\
\text { log. basal IRI }\end{array}$ & $\begin{array}{l}\text { body weight } \\
\text { body weight } \\
\text { log. body weight }\end{array}$ & $\begin{array}{l}0.152 \\
0.214 \\
0.144\end{array}$ & $\begin{array}{l}\text { N.S.a } \\
\text { N.S. } \\
\text { N.S. }\end{array}$ & & $\begin{array}{l}0.155 \\
0.161 \\
0.198\end{array}$ & $\begin{array}{l}\text { N.S. } \\
\text { N.S. } \\
\text { N.S. }\end{array}$ & & $\begin{array}{l}0.083 \\
0.064 \\
0.045\end{array}$ & $\begin{array}{l}\text { N.S. } \\
\text { N.S. } \\
\text { N.S. }\end{array}$ & \\
\hline $\begin{array}{l}\text { IRI after load } \\
\text { IRI } 10 \mathrm{~min} \text { after load } \\
\text { IRI } 20 \mathrm{~min} \text { after load } \\
\text { IRI } 60 \mathrm{~min} \text { after load }\end{array}$ & $\begin{array}{l}\text { body weight } \\
\text { body weight } \\
\text { body weight } \\
\text { body weight }\end{array}$ & $\begin{array}{l}0.458 \\
0.509 \\
0.441\end{array}$ & $\begin{array}{l}<0.001 \\
<0.001 \\
<0.001\end{array}$ & $\begin{array}{l}0.821 \\
0.720 \\
0.504\end{array}$ & $\begin{array}{l}0.613 \\
0.519 \\
0.375\end{array}$ & $\begin{array}{l}<0.001 \\
<0.01 \\
<0.05\end{array}$ & $\begin{array}{l}1.092 \\
0.610 \\
0.279\end{array}$ & $\begin{array}{l}0.296 \\
0.512 \\
0.482\end{array}$ & $\begin{aligned} & \text { N.S. } \\
< & 0.001 \\
< & 0.01\end{aligned}$ & $\begin{array}{l}0.908 \\
0.748\end{array}$ \\
\hline $\begin{array}{l}\text { log. IRI area } \\
\text { Insul. Index }\end{array}$ & $\begin{array}{l}\text { body weight } \\
\text { body weight }\end{array}$ & $\begin{array}{l}0.614 \\
0.462\end{array}$ & $\begin{array}{l}<0.001 \\
<0.001\end{array}$ & $\begin{array}{l}0.702 \\
3.122\end{array}$ & $\begin{array}{l}0.638 \\
0.491\end{array}$ & $\begin{array}{l}<0.001 \\
<0.01\end{array}$ & $\begin{array}{l}0.614 \\
2.843\end{array}$ & $\begin{array}{l}0.593 \\
0.452\end{array}$ & $\begin{array}{l}<0.001 \\
<0.01\end{array}$ & $\begin{array}{l}0.845 \\
3.949\end{array}$ \\
\hline
\end{tabular}

a N.S. = not significant $(p>0.05)$.

4 min after the glucose load we find in all subjects a striking elevation of plasma IRI. But the differences between the mean values observed in the patients and the mean observed in the controls fall short of significance because the standard errors are large : apparently the early plasma IRI increase after glucose varies greatly between different subjects belonging to the same group.

All the obese patients (O, OD1, OD2) show an important elevation of plasma IRI, 10,20 , and $60 \mathrm{~min}$ after the load. At 20 and $60 \mathrm{~min}$, the plasma IRI of the

\section{Correlations between plasma IRI and body weight.}

Disregarding the differences between groups we studied the relations of plasma IRI and body weight in all the 79 patients. We considered also separately the 35 non diabetic patients $(\mathrm{N}, \mathrm{M}, \mathrm{O})$ and the 44 diabetic patients (D1, D2, OD1, OD2). The results are recorded on Table 3 .

We find no significant correlation between basal plasma IRI and body weight whether we use the original data or their common logarithms. But after the glucose load, the insulin level correlates well with body weight 
in all the 79 subjects and in the 35 non diabetics. In the diabetics the correlation is not significant 10 min after the load but highly significant 20 and $60 \mathrm{~min}$ after the load. In all groups we find a good correlation between the insulinogenic index and the body weight. The highest correlation coefficients are found between log IRI area and body weight.

The regression coefficients " $b$ " observed in the non diabetic group are not significantly different from those observed in the diabetic patients.

\section{Correlations between insulinogenic index and age}

It is seen on Table 1 that the mean age of the overt diabetics is higher than the mean age of the corresponding controls. The difference is highly significant between the controls $(\mathrm{N})$ and the diabetics (D2): $\Delta=$ $27, p<0.001$. The difference is less striking between the obese patients (O) and the obese diabetics (OD2): $\Delta=9, p \leq 0.05$. This observation led us to look for a correlation between plasma IRI and age. is likely that the transformation of a latent diabetes to an overt diabetes depends not on an impairment of insulin secretion. It may rather be related to insulin resistance due to significant elevation of body weight $(\Delta=17.4 \mathrm{~kg}, p<0.02)$. The difference of age between the D1 and D2 patients is not significant $(\Delta=10.8$ years, $p>0.10$ ).

It is also noteworthy that the undernourished anorexia nervosa patients (M) have a normal basal IRI value and a normal insulin response to glucose. It must be emphasized that we selected only patients who had normal " $K$ " and fasting blood sugar values.

In the literature there are conflicting reports on the correlations between plasma insulin and body weight. Bagdade et al. $[2,3,4]$ find a close correlation between basal IRI and body weight. They relate also the magnitude of the IRI response to oral glucose to the level of basal IRI [3]. In an important study performed on the white and blue collar workers of a big factory, Rosselin et al. [31] confirm Bagdade's views. Even in

Table 4. Correlation between the insulinogenic index (y) and age $(x)$

\begin{tabular}{llrrr}
\hline Patients & $n$ & $r$ & \multicolumn{1}{c}{$p$} & \multicolumn{1}{c}{$b$} \\
\hline All subjects & 79 & -0.212 & N.S. & \\
Non diabotics (N-M-O) & 35 & 0.000 & N.S. & \\
Diabetics (D1-D2-OD1-OD2) & 44 & -0.430 & $<0.01$ & -8.84 \\
Obese (O-OD1-OD2) & 41 & -0.497 & $<0.001$ & -12.55 \\
Non obese (N-M-D1-D2) & 38 & +0.151 & N.S. & \\
\hline
\end{tabular}

a N.S. = not significant $(p>0.05)$.

We found no correlation between basal IRI and age in any of the groups or subgroups studied. All the correlation coefficients are very low even if we use the logarithms of the original values. But we find a significant negative regression of the insulinogenic index over age in the obese patients (O-OD1-OD2) and in the diabetic patients (D1-D2-OD1-OD2). We find no correlation between these parameters in the non diabetic patients and in the non obese subjects. Considering all the 79 subjects, the correlation is not significant (see Table 4).

\section{Discussion}

Numerous studies have shown that the plasma IRI level is higher in obese patients (whether they are diabetic or not) than in normal weight controls. It has also been shown that, in obese patients, the overt diabetic state is associated with a relative reduction of plasma IRI $[1,3,6,7,10,20,22,27,32]$. In this study both basal and reactive IRI is high in the obese patients. The mean value observed 10 and 20 min after the load in the overt obese diabetics (OD2) is reduced when compared to the $\mathrm{O}$ and OD1 patients. We do not find this difference in the normal weight diabetics D1 and D2. Both groups have the same high plasma IRI in the basal state and after the load. In these patients it maturity onset diabetes, Goodner et al. establish a significant regression of plasma basal IRI on body weight [15]. On the other hand Deckert and Hagerup find no correlation between these parameters in obese and normal subjects [13]. Vague et al. observe that hyperinsulinism correlates better with the android type of obesity than with body weight [35].

We are not able fo find a significant correlation between basal plasma IRI and body weight (Table 3). The discrepancy between these results and those of Bagdade et al. and Rosselin et al. could be explained by methodologic difficulties: the acurate determination of small amounts of plasma IRI is technically difficult. The criteria used for the selection and grouping of the patients may also bias the results.

We find significant correlations between the reactive plasma IRI levels determined after the glucose load and body weight. (Table 3). We emphasize particularly the significance of the relationship between the logarithm of the IRI area or the insulinogenic index, and the body weight in diabetic as in non diabetic patients. These facts could be expected as the glucose load is porportional to body weight.

In preliminary studies we found:

1. a positive correlation between the plasma glucose area and the absolute amount of the glucose load $(r=+0.643-n=79-p<0.001)$ 
2. A positive correlation between the logarithm of the plasma IRI area and the absolute amount of the glucose load $(r=+0.622-n=79-p<0.001)$.

3. A positive correlation between the logarithm of the plasma IRI area and the plasma glucose area $(r=$ $0.482-n=79-p<0.001$ ). So it appears, once more, that, in this type of study the insulinogenic index of Seltzer et al. is of fundamental importance. In this study, the index grows directly with body weight, so it can be stated that the insulin response to a glucose load is probably determined by the body weight.

According to Bagdade et al. [3] the insulin response to glucose is also a direct function of the basal IRI value. Considering the whole group of the 79 patients, we find a positive correlation between the insulinogenic index and the basal IRI $(r=+0.376-n=79-p<$ $0.01)$. This correlation is closer in the normal controls (N) $(r=+0.585-n=13-p<0.05)$ and in the undernourished patients (M) $(r=+0.754-n=8-p<$ $0.05)$. This indicates that the same undetermined factors influence the insulin level both in basal conditions and after a glucose load. This factor is probably not the fasting blood sugar value because we found no valid correlation between basal IRI and basal plasma glucose, neither in the non diabetic group $(r=0.000)$ nor in the diabetics $(r=0.168-p>0.10)$.

Conflicting data on the influence of age on plasma insulin have been reported. Chlouverakis et al. [9] and Streeten et al. [34] find a hyperinsulinism in old age whereas Crockford et $a l$. [12] and Franckson et al. [14] find a reduced insulin secretion perhaps related to a senile involution of the islets of Langerhans. Marigo describes an early phase of hyperinsulinism followed by hypoinsulinism, in old age [23]. Welborn et al. [36] and Boyns et al. [8] find no valid correlation between plasma insulin and age. Mirouze et al. find a reduced insulin output after an oral glucose load in elderly diabetics [25].

We found no correlation between basal IRI and age in the different groups and subgroups studied. But the insulinogenic index decreases with age in the diabetics and in the obese patients (Table 4). This suggest that, in certain conditions, leading to an overt diabetes, the insulin response to a glucose load seems to decrease with advancing age. We are inclined to relate the reduced glucose tolerance in old age to a diminished responsiveness of insulin secretion.

\section{References}

1. Azerad, E., Lubetzki, J., Duprey, J., Friedler, D.: Etude de la sécrétion insulinique au cours des per. fusions de glucose chez des sujets normaux et diabétiques, p. 157-177. Journées Diabétologie Hotel Dieu: Flammarion Edit. 1969.

2. Bagdade, J.D.: Basal insulin and obesity. Lancet 1968 II, $630-631$

3. - Bierman, L., Porte, D.: The significance of basal insulin in the evaluation of the insulin response to glucose in diabetic and non diabetic subjects. J. clin. Invest. 46, 1549-1557 (1967).
4. - Porte, D. Jr., Bierman, E.L.: The interaction of diabetes and obesity on the regulation of fat mobilization in man. Diabetes 18, 759-772 (1969).

5. Beck, P., Koumans, J.H.T., Winterling, C.H., Stein, M.F., Daughaday, W.H., Kipnis, D.M.: Studies of insulin and growth hormone secretion in human obesity. J. Lab. clin. Med. 64, 654-667 (1964).

6. Boeuf, G., Vague, Ph.: Le dosage radio-immunologique de l'insuline plasmatique dans le diabète et les obésités. Le Diabète 15, 185-195 (1967).

7. Boshell, B.R., Ghandalia, H.B., Kreisberg, R., Roddam, R.F.: Serum insulin in obesity and diabetes mellitus. Amer. J. clin. Nutr. 21, 1419 - 1428 (1968).

8. Boyns, D.R., Crossley, J.N., Abrams, M.E., Jarrett, R.J., Keen, H.: Oral glucose tolerance and related factors in a normal population sample. I blood sugar, plasma insulin, glyceride and cholesterol measurements and the effects of age and sex. Brit. med. J. 1969 I, $595-596$.

9. Chlouverakis, C., Jarrett, R.J., Keen, H.: Glucose tolerance, age and circulating insulin. Lancet $1967 \mathrm{I}$, $806-809$.

10. Colwell, J.A., Lein, A.: Diminished insulin response to hyperglycemia in prediabetes and diabetes. Diabetes 16, $560-565(1967)$.

11. Conard, V., Franckson, J.R.M., Bastenie, P.A., Kestens, J., Kovacs, L.: Etude critique du triangle d'hyperglycémie intraveineux chez l'homme normal et détermination d'un coefficient d'assimilation glucidique. Arch. int. Pharmacol. 93, 277-292 (1953).

12. Crockford, P.M., Harbeck, R.J., Williams, R.H.: Influence of age on intravenous glucose tolerance and serum immunoreactive insulin. Lancet $1966 \mathrm{I}, 465-$ 467.

13. Deckert, T., Hagerup, L.: Serum insulin in normal and obese persons. Acta medica scand. 182, 225-232 (1967).

14. Franckson, J.R.M., Malaisse, W., Arnould, Y., Rasio, E., Ooms, H. A., Balasse, E., Conard, V., Bastenie, P. A.: Glucose kinetics in human obesity. Diabetologia 2, 96-103 (1966).

15. Goodner, C.J., Werrbach, J.H., Conway, M.J.: Studies of the regulation of insulin, glucose and FFA in hyperglycemic adult onset diabetes (Abstract). Diabetes 18, 357 (1969).

16. Grodsky, G.M., Forsham, P.M. : An immunochemical assay of total extractable insulin in man. J. clin. Invest. 39, 1070-1079 (1960).

17. Hales, C.N., Randle, P.J.: Immunoassay of insulin with insulin antibody precipitate. Biochem. J. 88, $137-146$ (1963).

18. Hales, C.N., Randle, P.J.: Effects of low carbohydrate diet and diabetes mellitus on plasma concentrations of glucose, non esterified fatty acid and insulin during oral glucose tolerance tests. Lancet 1963, $790-794$.

19. Hollobaugh, S.L., Boshell, B.R.: Direct evidence for increased insulin turnover in obesity. (Abstract). Diabetes 18, 359 (1969).

20. Karam, J.H., Grodsky, G.M., Forsham, P.H.: Excessive insulin response to glucose in obese subjects as measured by immuno-chemical assay. Diabetes 12, $197-204$ (1963).

21. Kreisberg, R.A., Boshell, B.R., Di Placido, J., Roddam, R. F. : Insulin secretion in obesity. New Engl. J. Med. 276, 314-319 (1967).

22. Luyckx, A., Lefebvre, P.: Evidence d'une réduction de la sécrétion d'insuline dans le diabète avec ou sans obésité. Discussion de l'emploi thérapeutique des biguanides. Ann. Endoer. (Paris) 30, 717-730 (1969).

23. Marigo, S.: The insulin secretion in old age. Acta Diab. Latina 5, (suppl. 1) 539-569 (1968).

24. Melani, F.: Critical considerations regarding the 
obesity-hyperinsulinism concept. Acta Diab. Latina 5, (suppl. 1) 332-340 (1968).

25. Mirouze, J., Orsetti, A., Lapinski, H.: L'insulinosécrétion de jeûne et de stimulation orale glucosée dans une population diabétique classée par groupes d'âge. 7th congr. Internat. Diabetes Fed., Buenos Aires 1970 (in press).

26. Ogilvie, R.F.: Sugar tolerance in obese subjects: a review of 65 cases. Quart. J. Med. 4, 345-358 (1935).

27. Perley, M.J., Kipnis, D.M.: Plasma insulin responses to oral and intravenous glucose: studies in normal and diabetic subjects. J. Clin. Invest. 46, 1954-1962 (1967).

28. Porte, D., Bagdade, J.D.: Human insulin secretion: an integrated approach. Ann. Rev. of Med. 21, 219$240(1970)$.

29. Rabinowitz, D., Zierler, K.L.: Forearm metabolism in obesity and its response to intra-arterial insulin. Characterization of insulin resistance and evidence for adaptive hyperinsulinism. J. Clin. Invest. 41, 21732181 (1962).

30. - - Role of free fatty acids in forearm metabolism in man quantitated by use for insulin. J. clin. Invest. 41, 2191-2197 (1962).

31. Rosselin, G.E., Claude, J.R., Eschwege, E.P., Patois, E., Warnet, J.M., Richard, J.L.: Diabetes Survey. Plasma insulin during $0-2 \mathrm{~h}$ oral glucose tolerance test systematically carried out in a professional group. Diabetologia 7, 34-45 (1971).
32. Seltzer, H.S., Allen, W.E., Herron, A.L., Jr., Brennan, M.T.: Insulin secretion in response to glycemic stimulus. Relation of delayed initial release to carbohydrate intolerance in mild diabetes mellitus. $J$. clin. Invest. 46, 323-335 (1967).

33. Snedecor, G.W.: Statistical Methods. The Iowa State University Press, 5th Edition 1966.

34. Streeten, D.H.P., Gerstein, M.D., Marmor, B.M., Doisy, R.J.: Reduced glucose tolerance in elderly human subjects. Diabotes 14, 579-583 (1965).

35. Vague, J., Vague, Ph., Boyer, J., Cloix, M. J. : Anthropometrie des obésités, diabètes, fonctions corticosurrénales et insulino-sécrétion. 7th congrès Internat. Diabetes Fed. Buenos Aires, 1970 (in press).

36. Welborn. T.A., Rubenstein, A.H., Haslam, R., Fraser, R. : Normal Insulin Response to glucose. Lancet 1966 I $280-283$.

37. Yalow, R.S., Berson, S.A.: Immunoassay of endogenous plasma insulin in man. J. clin. Invest. 39, 11571175 (1960).

38. - Glick, S.M., Roth, J., Berson, S. A.: Plasma insulin and growth hormone levels in obesity and diabetes. Ann. N. Y. Acad. Sci. 131, 357-373 (1965).

Prof. Dr. F. Stephan,

Clinique Endocrinologique,

F-67 Strasbourg, France 